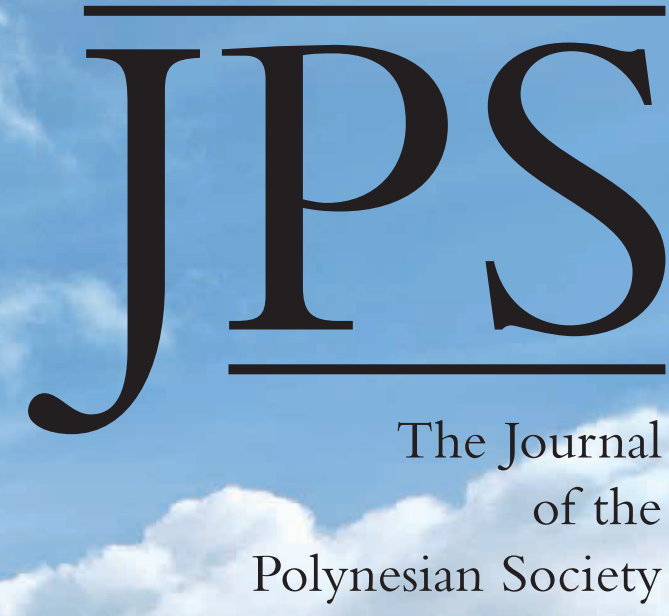

VOLUME 125 No.2 JUNE 2016

Special issue

GRAVE MATTERS IN OCEANIA

THE POLYNESIAN SOCIETY

THE UNIVERSITY OF AUCKLAND

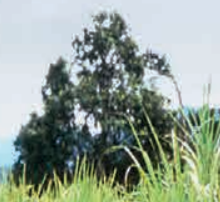

NEW ZEALAND

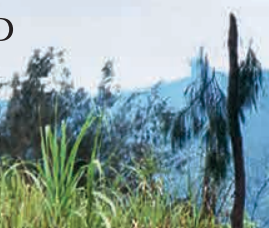

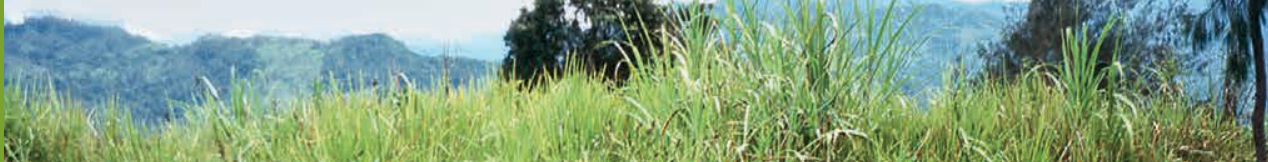

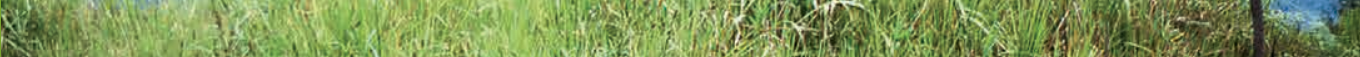

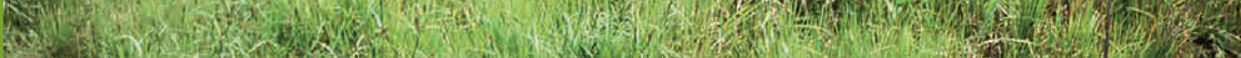

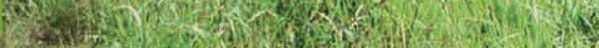




\title{
THE WORK OF THE DEAD IN SAMOA: RANK, STATUS AND PROPERTY
}

\author{
MALAMA MELEISEA and PENELOPE SCHOEFFEL \\ The National University of Samoa
}

The selection of a title for this paper, and a number of its insights owe much to Laqueur's cultural history of mortal remains in Western Europe (2015). Samoa was evangelised by both Protestant and Catholic missionaries in the early 19th century so that Samoan eschatology, along with other Samoan cultural institutions, blended pre-Christian beliefs with a variety of Christian doctrines on where the souls (agaga) of the dead go and what continuing relationships they have with the living. Graves convey more than sentiment; the selection of burial sites and the type of monuments chosen make visible statements about traditional rank, family status and claims to property, so that the dead continue to work for the living in spirit and by the location of their mortal remains. This paper examines what is known about burial practices, the location of graves and the manner in which they were marked in pre-colonial Samoa, and the changes that have occurred to these practices as a result of conversion to Christianity, 19th-century power struggles, political change, colonial influences and regulations, and 20th-century settlement patterns and practices. Customs have come full circle in Samoa from traditional burials near or under houses, to burials in village cemeteries by colonial decree, to a revival of traditional practices since the 1960s. We examine how the location of graves and their associated edifices reflect changes resulting from mass emigration and monetisation and modernisation of the economy, and how graves have become a means of asserting ownership over portions of customary land by individuals and their immediate relatives.

\section{TRADITIONAL BURIAL PRACTICES}

Burial was evidently of great importance to Samoans in ancient times as, according to missionary accounts, if a body was lost at sea or due to some other mishap, a tapa cloth would be prayerfully spread out and the first living thing that alighted upon it was received as a manifestation of the lost corpse (Turner 1848: 151). It was wrapped and interred according to the normal rites for the dead at their ancestral residential site. These sources also record the practice of locating graves close to houses (Krämer 1995: 112, Turner 1848: 146-47), and other accounts of burial practices drawn from historical sources, such as Mead (1969: 99) mention that sometimes there were burials under the stone platforms (paepae) that formed the floor and foundations of 
traditional houses. Archaeologists Roger Green and Epifania Suofo'a both told us that they had found human remains in paepae. Turner (1848: 146-47) also refers to the practice of mummification in which the corpse of a high chief was preserved within a house which may have served as a place of worship.

There has been debate among geographers and archaeologists about 18th-century settlement patterns, some maintaining that most villages were located inland and that the practice of locating villages on the coast was a post-contact practice (see Davidson 1969). However, the layout of villages and the way houses were built conformed to descriptions recorded as long ago as 1831 (Moyle 1984), and as recently as 1966 (Lockwood 1971). As far back as written records go, Samoan villages of any traditional importance were nucleated settlements located adjacent to a malae 'a central open space', which had sacred connotations in pre-Christian Samoa. Villages (the term $n u$ ' $u$ often translated as 'village' refers to a territory, not a settlement) may have maintained both coastal and inland settlements inhabited seasonally: coastal settlements for cool breezes, fishing grounds and fresh water, and inland settlements for the ancient sport of pigeon hunting and as places of refuge in times of war. The largest houses of the highest ranking chiefs were located close to the malae and other houses behind them, arranged in a circular pattern or in lines. Rank was a demonstrated by the stone platform of the faletele 'meeting house'; a house built on several stone tiers that was a jealously guarded privilege of the highest ali ' $i$ (Grattan 1948: 57-58). The height of paepae was echoed by the height of the drystone cairns that marked the graves of the highest ranking chiefs; the graves of those of lesser status were marked with a low rectangle of stones (Hiroa 1930: 322). Turner (1984: 142-43), referring practices in the mid-19th century, wrote that "the grave of a chief was neatly built up in an oblong slanting form, about three feet high at the foot, and four at the head".

Long ago, large man-made mounds may have been sites for the houses and burial places of paramount chiefs. There are many of these in Samoa (Freeman 1944, Thomson 1927); some are immense structures of earth or stone (Freeman 1944) and differ from smaller so-called 'star mounds' (tia seu lupe), which are known to have been constructed for the purpose of pigeon snaring (Herdich 1991). While well described, these edifices have only been subject to minor archaeological investigations, and their purpose is unknown because there are no surviving accounts or oral traditions to explain them (Martinsson-Wallin et al. 2006, Martinsson-Wallin et al. 2007). Their origin and functions have long been a source of speculation. It seems likely that they were once burial sites and important centres of ritual activity and, as preChristian Samoans were observed to have offered prayers to ancestral spirits at their grave sites (Turner 1848: 151), perhaps also sites of necromancy. In 
warfare, enemies would desecrate conspicuous tombs, so in troubled times the skulls of high chiefs were removed from graves and concealed (Krämer 1995: 112-13). The ritual for re-interring human remains is termed liutofaga and is still practiced; it involves opening of the grave, removing the bones, oiling them and, with accompanying prayers, wrapping them in tapa cloth for re-interment elsewhere.

Since the late 19th century the edifices (tia) marking the graves of ali $i$ have been typically shaped like rectangular pyramids with three stone tiers. For example, the 'äiga $S \bar{a}$ Meleiseā, like few other prominent Samoan

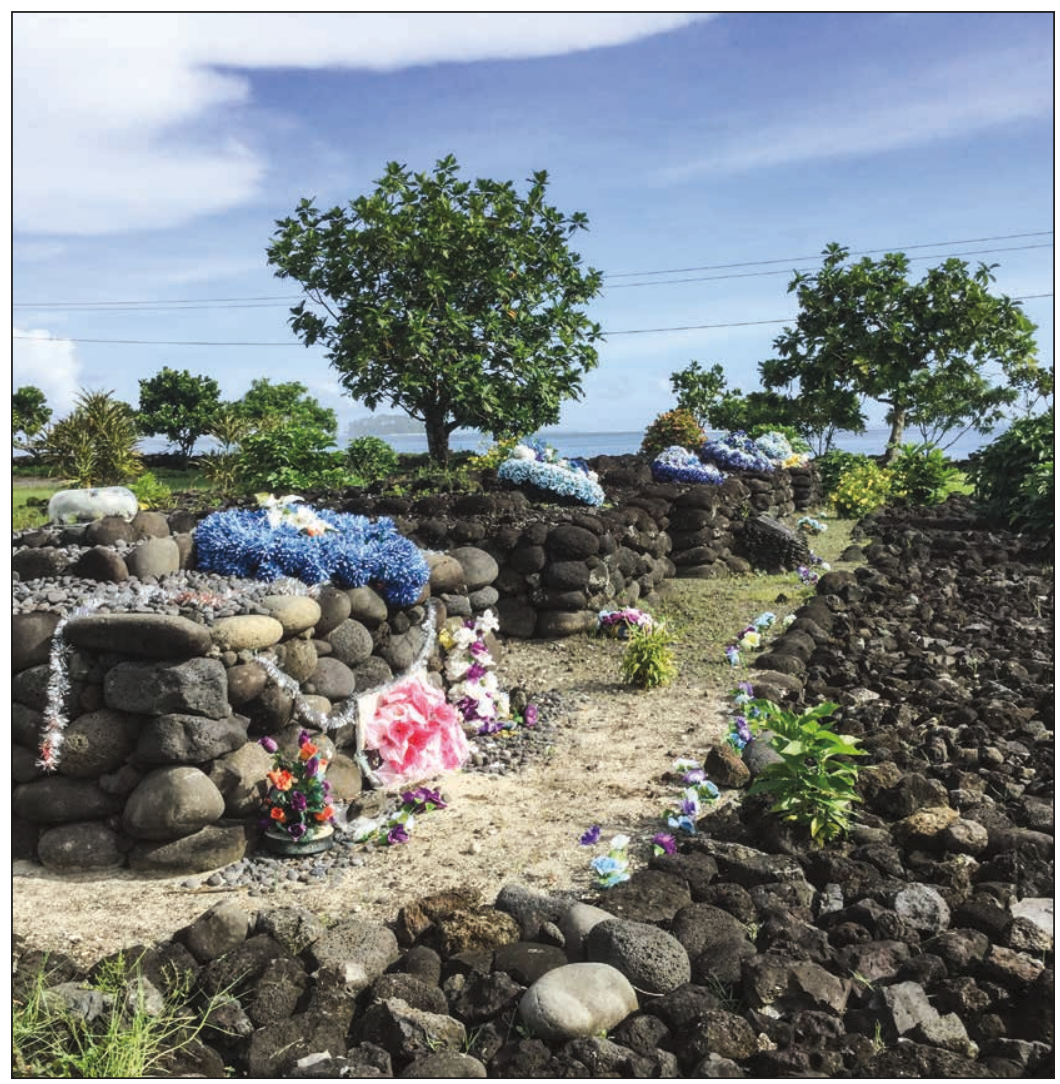

Figure 1. Meleiseā tia at Poutasi showing traditional dry-stone construction. 
families, has a large raised stone terrace edged with worked stone close to their maota 'site associated with a chiefly residence' containing many old anonymous graves (Fig. 1). Tia mark the burial places of the five previous holders of the Meleisea title, the oldest only dating back to the 1940s. The terrace is believed to be hundreds of years old, and the Meleiseā genealogy records that there were ten ancestral title holders who lived and died before those five marked by the tia. Several graves on the terrace are marked by large slabs of coral rock. These possibly indicate a different practice for the burial of ali $i$ in the past. As few unaltered graves from centuries past still exist anywhere in Samoa, it is hard to tell whether the styles have changed or whether their graves were concealed because of recurrent wars in the 19th century. Krämer provides an illustration of the tia of Malietoa Laupepa at Mulinu'u (1995: 112). While it covers a very large area, like others of the period it has only three tiers, suggesting that there may have been some modern escalation in the height of tombs. For example, the tia marking the grave of Malietoa Moli at Malie village is much bigger, with seven tiers, and appears to have been reconstructed since the original burial there in 1860 (Fig. 2). The tia of brothers holding the Mataia and Tagaloa titles at Vaitele are now surrounded by urban developments and were elaborately renovated in 2016 when the road was widened (Figs 3 and 4).

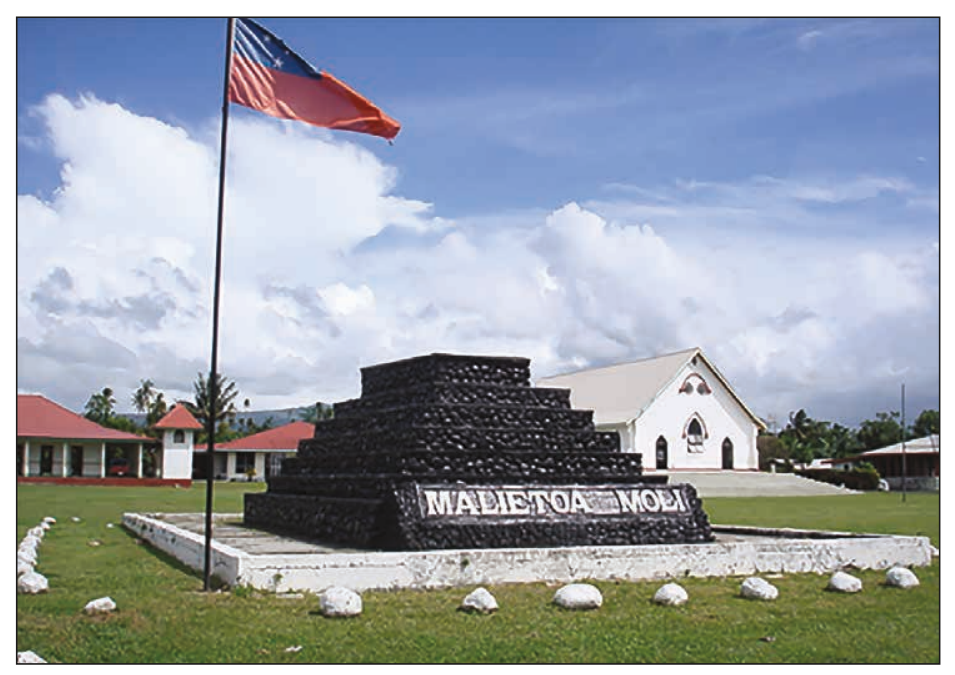

Figure 2. Tia of Malietoa Moli at Malie with modern elaborations. 


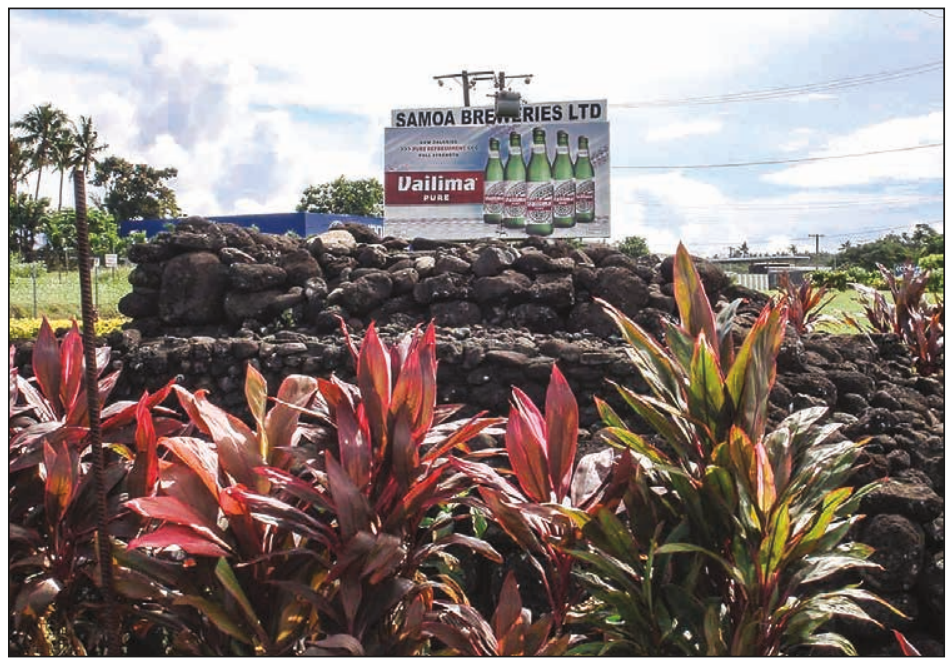

Figure 3. Mataia tia at Vaitele in its original form.

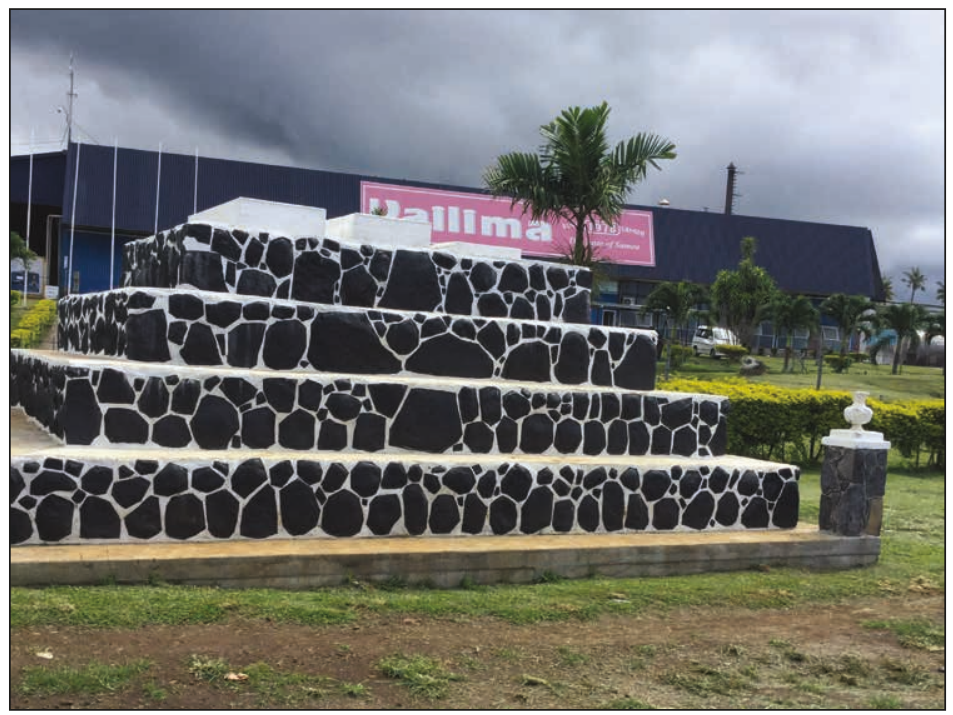

Figure 4. Mataia tia at Vaitele after renovation. 


\section{THE POLITICS OF BURIAL MONUMENTS}

The first mausoleums (loa) in Samoa appear to have been constructed in the late 19th century following an introduced practice, and the most elaborate of these came to symbolise the transfer of power from the traditional districts to a centralised state. An illustration in Krämer (1995: 113) captioned "the modern tomb of a chief" shows a small loa of what appears to be coral limestone cement (a technology introduced by missionaries) and the earliest of these may have been constructed to hold the disinterred bones of a number of important ancestors.

Imposing loa were constructed for Samoa's paramount chiefs of the 19th century and through the 20th century. To clarify, from pre-contact time and throughout the 19th century, Samoans regarded four ao "honorific titles' as paramount; any high chief who could secure all four of them was acknowledged as Tafa 'ifä 'Four in one' and as tupu 'king' of Samoa (Gilson 1970: 58-64). These honorifics were the focus of much of the political conflict and warfare that occurred in the 50 years before the Samoa Islands were was annexed and divided by Germany and the United States of America in 1900. Germany, in control of the more populous western islands of Samoa set out to enforce peace by abolishing these titles and establishing a system of government that excluded the orator groups who bestowed these honorifics (Meleisea 1987: 47-48). Since then the four high chiefly titles that are now regarded as paramount in Samoa are those that were involved in the precolonial contest to obtain the Tafa ifa and to become Tupu. The titles are Malietoa, Mata'afa, Tupua and Tuimaleali'ifano, referred to collectively as O Tama a 'Äiga (Tuimaleali'ifano 2006: 14-16). The Tama a 'Āiga have been laid in loa at Mulinu'u, a location that reflects the shift of paramount rank away from villages and districts to the headquarters of the Samoan National Government.

The first pre-colonial but western-style government of Samoa and the first king of Samoa (in the Western sense of the term "King") was Malietoa Laupepa, recognised by the Samoan factions and foreign powers in 1875. Owing to intrigues among the foreign settlers in Samoa, Laupepa was soon deposed by rivals, later re-instated, and then again deposed in a series of civil wars backed by rival factions among both the Samoans and the foreign settlers. Malietoa Laupepa died in 1898, at a time of great political conflict and so, according to family traditions (Monalisa Saveaali'i Malietoa, pers. comm. August 2015), he was first buried in a grave at his home at Papaloloa near Papauta, which was not a traditional maota of his title. Later, to recognise his earlier status as King of Samoa, he was re-interred, not at the maota of the Malietoa title, but on the Mulinu'u peninsula. Mulinu' $u$ was the seat of the several abortive pre-colonial national governments of Samoa (Gilson 1970: 
268-69) and it eventually became the site of a national malae named Tiafau. In the New Zealand colonial period the Legislative Assembly met there, and in 1962 it became the site of the National Parliament of the Independent State of Western Samoa.

The remains of Malietoa Laupepa were moved to Mulinu'u by the 'Āiga Sā La'auli and marked by a new tia there after his son Malietoa Tanumafili I had been declared King in 1889 (a position Tanumafili held only briefly, as

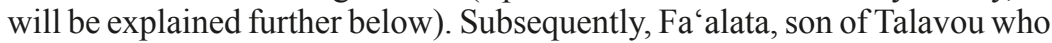
had been Laupepa's rival for the Malietoa title, was also buried at Mulinu'u, next to Malietoa Laupepa's tia (illustrated in Krämer 1995: 112). This was probably because $\mathrm{Fa}$ 'alata had been proposed by some branches of the Sā Malietoa as successor to Malietoa Laupepa (see Gilson 1970: 423) and his supporters wanted him to be given equal recognition by means of his burial place. In 1939, Malietoa Laupepa's remains were re-interred for the second time, this time they were placed in a loa that was built when his son Malietoa Tanumafili I died (Fig. 6). This mausoleum also holds the remains of Samoa's first Head of State, Malietoa Tanumafili II, who died in 2007.

It is likely that Mata'afa Iosefo, who died in 1912, was the first of the O Tama a 'Áiga to be interred in a mausoleum at Mulinu'u (Fig. 5), rather than at the seat of his title at Amaile. He had been recognised as King by all the Samoan factions in 1899 but this unanimity came too late. The Chief Justice of Supreme Court (established in Samoa by the Berlin Act of 1889 under an agreement between Germany, Britain and the USA) appointed Malietoa Tanumafili I as King. When the Samoans refused to recognise him (Tanumafili was then a boy of 19), warfare resumed and, as a result, in 1900 the three powers abandoned attempts to establish a national government under Samoan leadership and agreed to partition the Samoa archipelago between the United States and Germany. After Germany established its administration, Mata'afa Iosefa was designated Ali 'i Sili 'paramount chief' as part of the German strategy to eliminate monarchy as an institution in Samoa, and with it the martial quest among Samoan factions and the "king-making" orator groups Tumua and Pule to secure the four tafa 'ifa titles. The Mata 'afa loa holds his remains as well as those of subsequent holders of the Mata' afa title: Mata'afa Tupuola (died 1915), Mata'afa Muliufi, (died 1936), Mata'afa Mulinu'u I (died 1949), Mata'afa Mulinu 'u II (died 1975) and Mata'afa Fa'asuamaleaui Puela (died 1997) (Fiame Naomi Mata'afa, pers. comm. September 2015; see also Tuimaleali'ifano 2006: 24).

The remains of two holders of the Tuimaleali' ifano title lie in an imposing seven-tier concrete burial monument plastered in white, a design that echoes but greatly magnifies the traditional tia (Fig. 7). It was re-built in 1950s for the remains of Tuimaleali'ifano Fa'aoloi'i Si'ua'ana who died in 1937. 


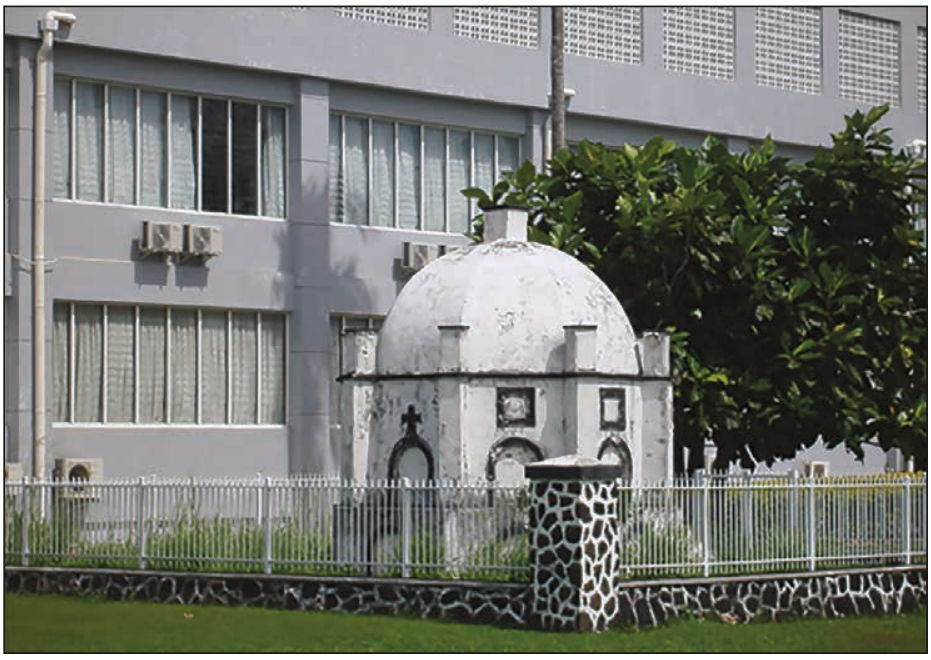

Figure 5. Mata'afa loa at Mulinu'u.

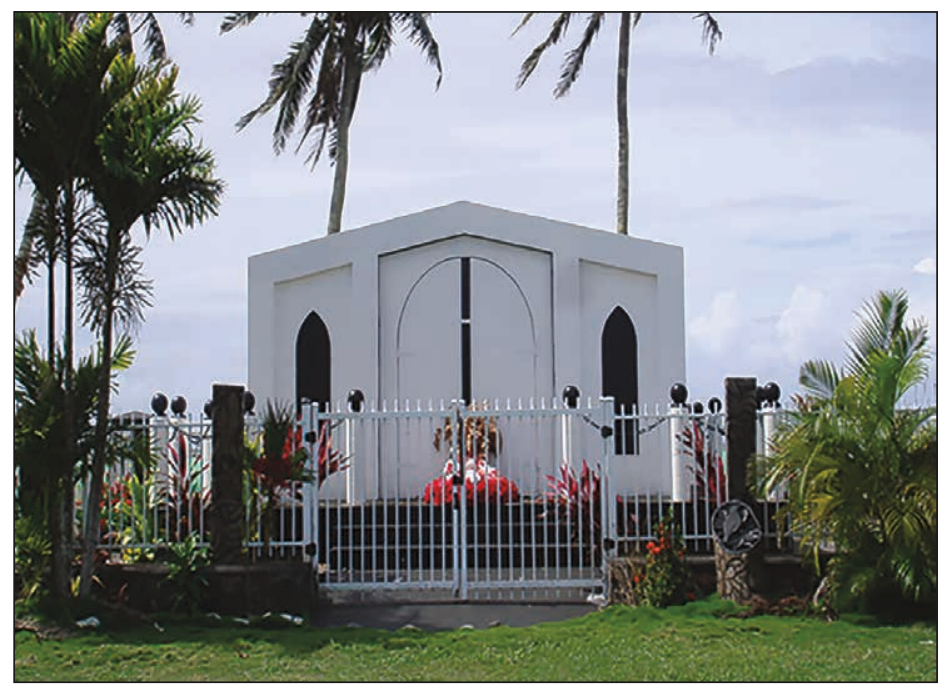

Figure 6. Malietoa loa at Mulinu'u. 


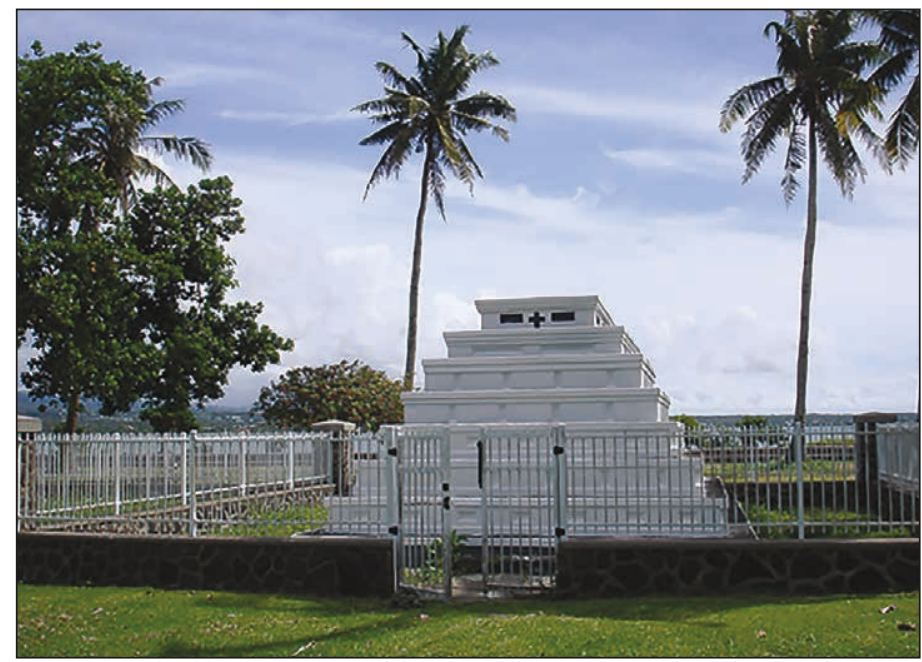

Figure 7. Tuimaleai'ifano loa at Mulinu'u.

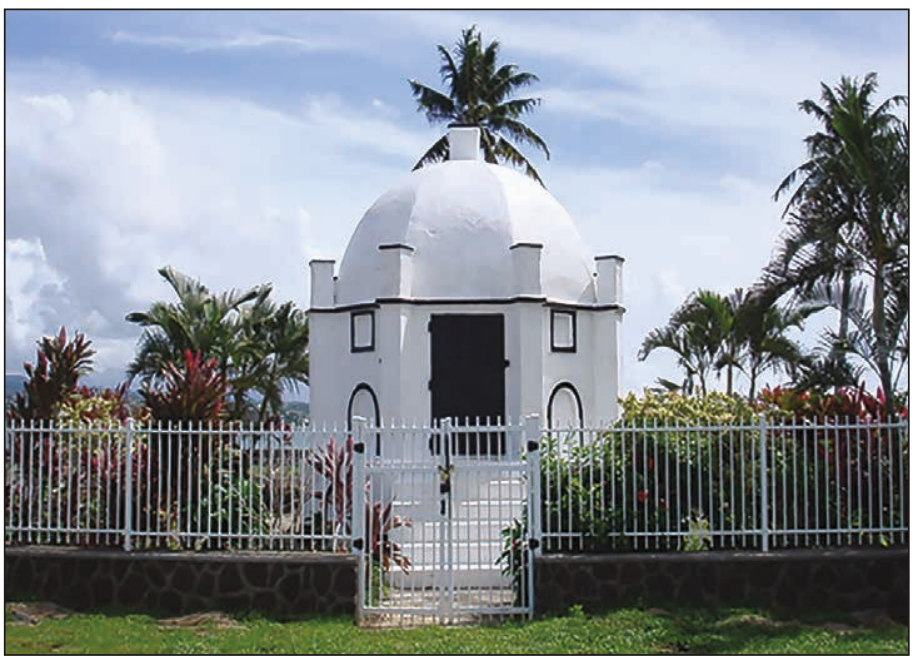

Figure 8. Tupua Tamasese loa at Mulinu'u. 
When Tuimaleali'ifano Suatipatipa II died in 1974, the top of the structure was opened and a liutofaga was performed for the bones of Tuimaleali'ifano $\mathrm{Fa}^{\text {'aoloi' }}$ i Si'ua'ana. These were wrapped and re-interred on top of Suatipatipa II's coffin. Another modern holder of the title, Tuimaleali'ifano Si'ua'ana II held the title for only nine months before he died in 1939 but was interred at the maota of Tuimaleali ifano at Matanofo in Falelatai, where according to family traditions other important ancestors of the linage have been re-interred (Morgan Tuimaleali'ifano, pers. comm. October 2015).

The remains of four holders of the Tupua Tamasese title are contained in a loa at Mulinu'u (Fig. 8). Tupua Tamasese Titimaea was originally buried in 1891 at Lufilufi, but his remains were transferred with a liutofaga to the new mausoleum at Mulinu'u by his son, Tupua Tamasese Lealofi I, who himself died shortly afterwards in 1915, and was also laid within it (Fig. 9). The remains of Tupua Tamasese Meaole, who became co-Head of State with Malietoa in 1962 and died in 1963, are also laid in it, as are those of Tupua Tamasese Lealofioa'ana IV, who died 1983. Two holders of the title were not interred at Mulinu'u. Tupua Tamasese Lealofioa'ana II died of influenza in the 1918 epidemic and, according to his own instructions before he died, was buried at Tafitoala, a village on the south coast of Upolu (Tuia'ana Tupua Tamasese Efi, pers. comm. October 2015). The grave of Tupua Tamasese Lealofioa' ana III is located close to the malae of the urban village of Lepea, close to where he lived at that time. He was a leader of the Mau Rebellion against New Zealand colonial rule and was shot and killed in 1929 by New Zealand police while leading a peaceful protest march. His huge tia is located beside the main road, in front of a number of old graves that are marked only with stones. The original tia built after his death was constructed of dry stones in the traditional manner, but it was renovated and enlarged in the late 1960s. The stones were cemented together and a plaque added, bearing his photograph and an epitaph recording the circumstances of his death, and his last words calling upon Samoa not to avenge his death and protest peacefully.

In the 1920s, the New Zealand colonial administration required each village to establish a cemetery some distance inland of the village on the ground of public health and hygiene. In addition to village graveyards, some extended families established their own small cemeteries, also on customary land outside the village. Special permission had to be sought to bury high ranking ali $i$ in traditional burial places within the village (Grattan 1948: 57). Burial practices changed rapidly after Samoa became independent in 1962. The Independent Government ceased to dictate to village councils where burials should be located, instead imposing requirements under health regulations for the interior of graves to be sealed with concrete. The Constitution of 


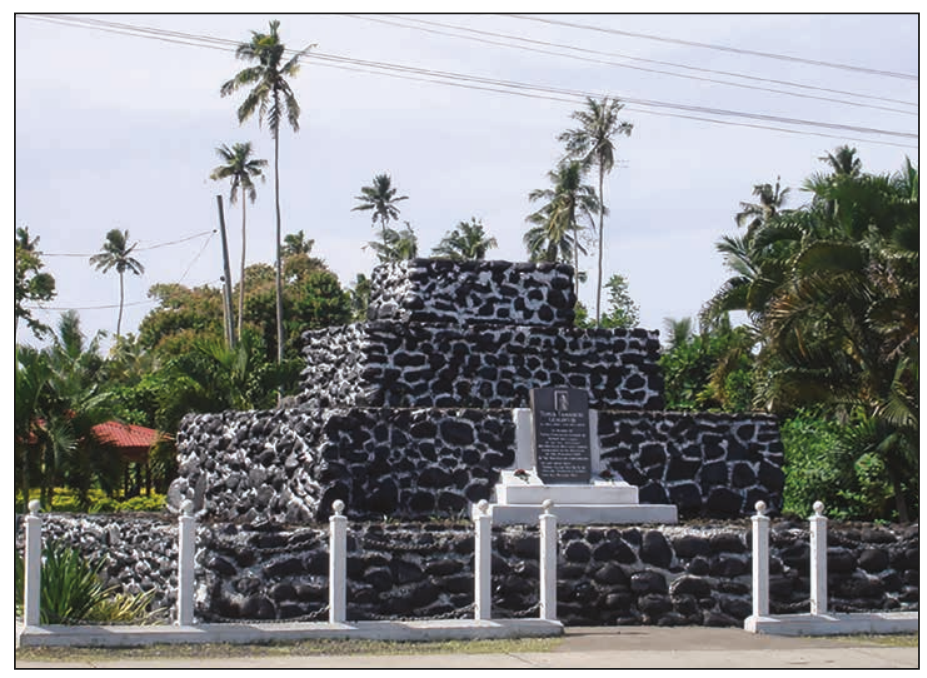

Figure 9. Tamasese Lealofioa'ana III tia at Lepea

Samoa recognises Samoan custom with three provisions relating to land and leadership and the arbitration of customary matters (along with the body of formal laws passed by the Parliament and subject to the Courts). The Village Fono Act (1990) permits the exercise of authority by the village councils of traditional villages in accordance with "custom and usage of their villages". The councils appoint sub-committees for local services such as schools and water supply as they see fit, and may intervene in decisions by families about the location of graves if they are perceived to contravene village traditions.

\section{GRAVES AND CLAIMS TO LAND}

Today, burials in household compounds are signs of affection for departed family members, but they also serve a further purpose of defining claims to property in an environment of uncertainty about customary rights. As Samoans began to migrate in large numbers to New Zealand and the United States in the late 1960s, and later to Australia, they sent money home to their families to build houses of permanent materials. This produced not only a variety of new house styles based on both traditional and foreign designs (see Van der Ryn 2012), but also made way for major changes to the way houses were located. The new economics of housebuilding made it more risky to build 
on the traditional house sites appurtenant to high ranking titles. According to traditional practices these sites pass into the possession of each successive senior holder of the title, at times dispossessing the family of the previous titleholder (if someone who was not closely related to them inherits the title). Accordingly, new houses built with remittance money and representing a large investment by the immediate family are built away from the old centre of the village, on what was formerly bush or plantation land, usually beside roads. Today graves are most commonly located in front or at the side of houses, in some cases suggesting the Samoan cultural associations of space and rank (see Duranti 1992). Graves are also often located in the middle of an area of empty land, signalling that the descendants of the person or persons interred there claim ownership of that the land and intend to build on it or cultivate it in the future.

Burial locations in Samoa have changed over the past 50 years as a result of new settlement patterns; most houses in contemporary villages are dispersed along roadsides. Customary land tenure no longer conforms to principles and practices documented in the early 19th century, and modern practices have been described as "customary individualism" by O'Meara (1987). In the past, the highest ranking chiefs of large lineages allocated and re-allocated use rights to land and retained authority over it regardless of who was actually using it. This flexible system both upheld the importance of the high chiefs and made sure everyone had access to resources according to their needs. It was well-suited to a subsistence economy. However, by the 20th century, after nearly a century of Christian and other foreign influences, the principle was established by the Land and Titles Commission (later the Land and Titles Court) that customary land belongs to families (Schultz 1911) and today a 'family' ('aiga) is usually more narrowly defined than in the past. In the past, in this context, a family was often a collective comprising a high ranking ali ' $i$ title, a number of historically related and subordinate matai titles, and all those related to and serving these titles. Nowadays with the levelling of rank (see Meleisea 1987) the trend is for all matai, irrespective of the rank of their title, to consider themselves independent of the highest title with which they were historically associated and with rights to land that are also independent of the high ancestral title.

Some villages still have tracts of common land under the traditional jurisdiction of the village council, such as inaccessible mountain forests and uncultivable lava fields. Customary land cannot legally be sold or mortgaged, but can be leased under the Alienation of Customary Land Act 1965. Further, non-citizens may not buy freehold land. Recently, with funding from the Asian Development Bank, measures are being put in place to alter the customary land-leasing framework and to set up a database of leased and leasable land, 
probably with the aim of developing a registry of all customary land. These measures may allow the possibility of leasing land to non-citizens, and so have triggered anxieties that foreigners are being empowered to acquire customary land by stealth (see Meleisea and Schoeffel 2015).

Although Samoans still describe their customary land tenure as though there had been no historical change, as a system in which land is held on corporate basis by matai to be used by the extended family of the matai who render service to him, people's actual beliefs and behaviour do not match those principles (O’Meara 1987, 1995, 1990). Most people believe that the customary land they occupy is the property of their immediate family, often nuclear families, and consider that rights to it will be inherited exclusively by the children of the present landholders, regardless of whether or not they are matai. Customary land has slowly and informally become divided into small farms and residential compounds owned or claimed by nuclear families. At present, registration of customary land in ways that confirm ownership of it is not widely accepted; to register land would probably provoke competing claims from people living elsewhere, who may consider they also have hereditary rights to it. People are also likely to fear the uncertain outcome of disputes taken to the Lands and Titles Court (see Meleisea and Schoeffel 2015).

Claims to property rights are strengthened by the location of graves. Graves located in front of houses make a statement that the house and the land on which it is built belong to the descendants of the person or persons buried there. When tombs are not located on traditionally recognised maota, families can give free rein to their own perceptions of their social status; tombs of lesser ranking matai sometimes exceed those of higher ranking matai in height. As described above, high chiefly rights to tia are related to the rank of a title and if the height of a tia marking a grave exceeds the rank of the person interred below it, an appeal to the Land and Titles Court may be made. Some villages only allow the building of two-storey houses by the holders of high ali $i$ titles or for housing the village pastor, so are likely to be vigilant in ensuring that the height of a tia matches the rank of the person interred below it. However, appeals to the Land and Titles Court against the families of those who have constructed graves that exceed their rank entitlements are infrequent. This is because ostentatious tia or other edifices marking graves are rarely located on traditional maota; nowadays huge loa or tia or modern grave monuments signal the wealth of a family rather than its claims to traditional rank. The size of a grave makes a statement about the importance of the deceased even if the grave is not located at the traditional maota. For example, in the 1980s Meleiseā Folitau I was buried below a tia, beside the tia of his father and grandfather on the maota appurtenant to the Meleiseā title they had successively held. Following his death, the 
title was split as a result of a decision by the Land and Titles Court. It was bestowed on two claimants to the title, Meleiseā Meafou a half-brother of the deceased, and Meleiseā Fano who, like his father and grandfather before him, had resided with the Meleiseā family but was not of their lineage. When Meleiseā Fano died, his brother and children asserted the right to bury him with a tia at the maota beside Meleiseā Folitau I, and where Meleiseā Meafou was later buried. The descendants of Meleiseā Folitau I and Meleiseā Meafou refused to allow Meleiseā Fano to be buried at the maota of the title on the grounds that he was not of their lineage. After their objection was upheld by the Land and Titles Court, Meleiseã Fano was buried in a tia that was considerably larger than those of the other Meleisea title holders, in the middle of a large section of land appurtenant to the Meleiseā title that they all shared. While this burial site had no traditional importance, it was in a prime location beside the main road, enabling Meleiseā Fano's heirs to both declare his status with large tomb and to lay an unassailable claim to a valuable portion of land.

Many Samoan families treat freehold land as though it were customary land. Since the 1960s, the government has subdivided areas of state-owned peri-urban land, mainly quarter-acre sections, and sold these with freehold title. The Congregational and Catholic churches have also sold subdivided peri-urban land in this manner. Freehold land is now extremely expensive, selling for between SAT 50,000 to 150,000 (approximately USD 20,000 to USD 58,000) per quarter acre, but banks value freehold land with graves on it at less than a quarter of the value it would realise without a grave or graves on it, even though it seems unlikely that a Samoan would sell land without first removing the remains of a family member buried there. Owners of freehold sections purchased since the 1970s appear seldom to make wills that bequeath their property to an individual; instead the land and the house on it (if a house has been built) is considered the property of all his or her descendants. For example, a civil servant who purchased a section of freehold land in a new urban subdivision in the 1970s did not build on it and died intestate. By law, his wife inherited the title deed of ownership. She gave the deed to one of her sons, who used it to secure various bank loans. With one of these loans he built a house on that section of land for his mother, but after a time was unable to make the repayments. The deed was transferred to his younger brother who eventually paid off the mortgage. Regardless of the legalities, the 12 children of the original owner regarded the house and the land as a collectively-owned family property. When their mother died, her children decided to bury her in front of that house, extending the front veranda to accommodate her modern tomb and headstone. They had considered several options before making this decision. One was to locate her grave in her husband's village next to a 
family house there. Another option was locate it in her village of origin, thus reinforcing family ties with her kin in that village. Yet another was to bury her in the nearby public cemetery. However, the majority favoured burying her at the house where she had lived. Aside from affection, a consideration in favour of the chosen option was that it would deter the family member who legally owned the house from selling it to recoup money that had been owed to the bank for the building of the house.

The tombs of ministers of religion raise some interesting issues. Although a church minister outranks even the highest ranking matai, they are not permitted to hold matai titles so they do not have traditional maota for their graves. Ministers are usually guests of the village and are not permitted to serve in villages where they have close family connections. Churches in Samoa rarely, if ever, had tombs within them, or graveyards around them in the European manner. In medieval Catholic Europe, spiritual advantage was incurred by those interred close to the remains of saints in tombs within the churches, or encased in reliquaries. The church claimed possession of the dead and determined who might lie in consecrated spaces within or around a church. The Protestant Reformation was supposed to have blown away such superstitious notions, yet we have observed Protestant churchyards still used as burial places in small towns in Denmark and Sweden, as they are said to be throughout Europe. In Samoa most village churches are built on customary land gifted to the church by a high chief of that village. The gift is for the exclusive use of the church, not for the burial of other persons; hence no graveyards or tombs within churches exist. An exception is the late Cardinal Pio Taofinu' $u$ whose remains lie below the Apia metropolitan Cathedral of the Immaculate Conception. Further exceptions have been made in a number of cases where church ministers have died in office; some have been buried beside or in front of the church where they were serving. However, when a minister dies, having already retired from his parish, his burial place is decided on and provided by his extended family. This may be in front of a family home or elsewhere. For example, Fa'apusa, a pastor of the Congregational Church of Samoa, was interred in an inconspicuous grave on freehold land belonging to his late brother. This was because the pastor's own son was a serving pastor (who later died in office, and so was buried next to his church). The father and son had not lived in their own ancestral village for two generations. The extended family of the older deceased pastor interred him on the freehold land because there was some uncertainly about their status in their ancestral village, owing to a dispute over a traditional title. Some years later, when the dispute was settled, he was ritually re-interred on customary land in his ancestral village. 


\section{CONTEMPORARY BURIAL PRACTICES}

The custom of locating graves beside houses has been fully revived. Almost every village house, as well as many in town, has a grave or two nearby. A matai is more likely to be buried in a conspicuous tomb at the front of the house while other family members may be buried less conspicuously beside or even behind the house. According to old customs (now rarely observed), if a woman died while living in her husband's village she was, if possible, returned for burial in her own village. There is no longer a consensus about what the customary rules are for wives and mothers; each family does as it prefers and common practices are gradually evolving into new customs. Nowadays, families often inter their mother and father side-by-side near the family home. Many graves in rural as well as urban areas are incorporated into the structure of the house. For example, a family living on customary land in American Samoa decided to bury their father, a matai of the village, under a marble-faced tomb on the front veranda of their house. When their mother died, she was buried beside him below a matching tomb. Later, the children of this couple extended the house and the tombs are now side-by-side in the air-conditioned and furnished front room of the house where the family meets for evening prayers. In another case known to us, a family who lost their son

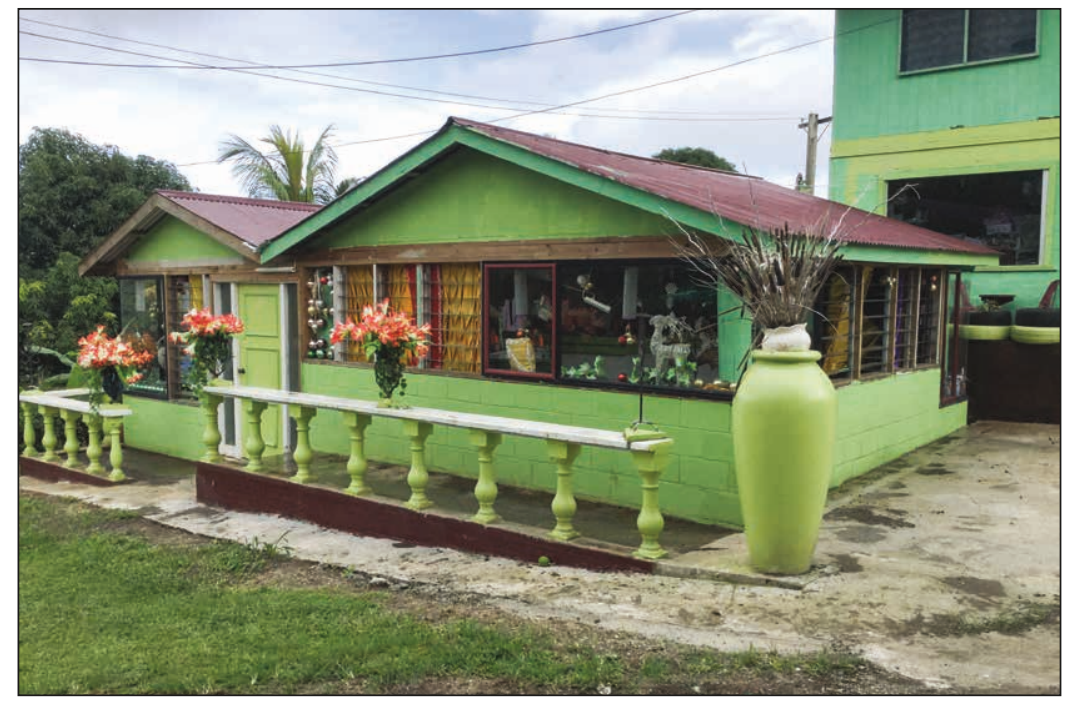

Figure 10. Family grave houses at Vailima. 
in a car accident decided to inter him under the house, his tomb is constructed within what had once been his bedroom. Graves beside or in front of houses are built in many styles; they may be enclosed by decorative wrought iron fences or, in an increasingly common practice, enclosed in small houses. The latter may be open-sided under a roof or completely enclosed with walls and with curtained glass windows. Roofs over tombs allow the preservation of gold lettered epitaphs and elaborate colourful silk and plastic flower wreaths that are given by relatives and friends at funerals. Once imported, headstones can now be commissioned locally; many are elaborate, featuring photographs of the deceased, decorative urns and statues of angels.

A newly borrowed and nowadays common practice is to hold ceremonies to unveil headstones at the first anniversary of a death, with prayer services, distribution of gifts and sharing of food. It is also increasingly common for families to construct family loa at their home or village maota. For example, the remains of several members of the Va'ai family were disinterred with a liutofaga from their graves in a town cemetery and relocated to a family loa that had been built in 2001 at the family home at Vaisala in Savai' $i$ for the remains of Va'ai Kolone, a former Prime Minister of Samoa (Silafau Sina Va'ai, pers. comm. October 2015). As the number of graves around houses increases, the practicality of a shared family loa is becoming increasingly recognised, and there are many imposing examples in villages throughout the country.

\section{SAMOAN ESCHATOLOGY AND THE LOCATION OF GRAVES}

Graves located around or adjoining houses affirm the affection in which those buried within are held and enable the living to preserve the memory of the dead. The graves of close family members are usually treated with affectionate familiarity as well as with respect; they may be used as a place to dry laundry, and youths and children may take naps on the cool surfaces of modern cement tombs with tiled or marble facing under roofs. At Christmas time, families often decorate tombs with fairy lights and other Yuletide decorations. Yet Samoans believe that ghosts (aitu) are ever-present among the living and many ghosts, who are well known in folklore, are thought to have been originated from someone who had once lived. However, the graves of close relatives built beside homes seldom cause concern about supernatural forces. Occasionally traditional healers may attribute misfortune or illness to the spirit of a deceased family member and there have been instances in which boiling water has been poured into a burial site to lay the offending spirit.

As well as the work of the dead in asserting property rights and status or rank, they exercise moral authority over the living. According to Turner (1984): 
The Samoans believed in a soul or disembodied spirit which they called the anganga [agaga] ... which at death was supposed to go away from the body and proceed to the hadean regions under the sea which they call Pulotu. (1894: 18)

Since the 1830s Samoan eschatology has been reshaped by the predominant Congregational or Methodist churches; today most believe that the souls of the dead go to heaven, where they rest in the company of their relatives. About one quarter of Samoans are Catholics, who believe it is necessary to pray for the dead, whose souls may be in purgatory, as only the most saintly go directly to heaven. Some smaller sects believe that the souls of the dead sleep in peace, awaiting the Day of Judgement before they reach heaven or hell. Despite various Christian doctrines, old beliefs are still widely held that the spirits of the dead-perhaps those from the so-called 'time of darkness' (aso o le pouliuli ) as the pre-Christian era is termed - may stay around on Earth in malevolent forms. Many illnesses are believed to be of ghostly origin and illness may be explained as the result of being struck by an offended spirit. Measures to avoid being struck by ghosts include covering mirrors with curtains to avoid attracting them, holding babies or small children so that they face forward, and not walking alone in the dark.

Another task of the presumably more righteous dead is to uphold moral values. Ghosts such as the legendary Sauma'iafe and Telesā are thought to punish young women for public vanity, such as wearing their hair loose or dressing immodestly, and ghostly attack may also punish misconduct among the living. For example, a young woman's mysterious illness was diagnosed by a traditional healer as a ghost sickness ( $m$ a ' $i$ aitu) caused by a ghost who struck her while the girl was walking from the inland plantation to her village. The angry ghost was identified by the healer as that of her grandfather, whose grave lay untended and forgotten among other graves in the old village cemetery. To make matters worse, people often behaved disrespectfully when they walked past the burial area. To put things right, the village council decided to disinter the bones of those buried in the old cemetery with liutofaga and to re-inter them in family tombs close to the village (Macpherson and Macpherson 1990: 99).

The dead sometimes need to remind the living about their mortal remains. Ghostly attacks have been associated with the discovery of previously unknown human remains. In one such instance, we were informed that a family had been troubled by strange noises at night, such as stones hitting the roof of their house, eventually discovered the cause. An unmarked grave containing the remains of several people was discovered near their house; possibly they were remains of people from the village who had died in the 
1918 Influenza Pandemic and who had been buried and forgotten. Such hasty burials were common because of the magnitude of mortality - one in every five Samoans died. Once the grave was opened and a liutofaga performed with a respectful reburial, the disturbances ceased.

\section{CEMETERIES}

The town of Apia has five public cemeteries which are managed by the Ministry of Natural Resources and Environment as part of its responsibilities for land management. The oldest is at Tufuiopa, close to the old Beach Road centre of Apia Township. Most of the tombs are those of European settlers. In 1879, the consuls of German, Great Britain and the United States established a self-governing municipal enclave in Apia, and the Tufuiopa cemetery appears to have been established around that time. Some Samoan families with European ancestors buried in this cemetery still maintain plots and bury family members there. The Magiagi cemetery has been in existence since the 1918 Influenza Pandemic. The cemetery was originally divided into two sections, one for Europeans and part-Europeans and the other for native Samoans from the nearby villages, including Magiagi. In the section for Samoan villages, some of the graves are marked only with low piles of stones without an identifying memorial plaque or headstone. It is likely that many people from these villages now bury family members near their houses rather than in the cemetery. Some families continue to use burial sections there, in small fenced areas or roofed structures and a few loa but, as mentioned previously, some families have disinterred deceased relatives from the cemetery and placed their remains in loa. The "European" section of the cemetery contains several small family mausoleums and many family burial places with rows of matching headstones or other memorial edifices, as well as graves within small open or enclosed houses in various styles.

The cemetery at Tafaigata is the location of the recently established crematorium (see Lilomaiava-Doktor, this volume), and has a memorial for the victims of the 2009 Tsunami and a mass grave for some of them. The Government invited the families whose relatives died in the tsunami to inter them there; however, many preferred to inter them in graves beside their houses following the widespread contemporary practice.

\section{THE WORK OF THE DEAD}

As Lilomaiava-Doktor (this volume) explains, the dead reunite the living at Samoan funeral services. Not only do they bring scattered families together from town and village and from far away cities, but the increasing scale and expense of funeral rites and burials make a very significant contribution to 
Samoa's economy. The beneficiaries include fabric printers and dress-makers who make the family funeral uniforms, sign-makers who supply memorial photographic badges, printers who produce the illustrated funeral service brochures, suppliers of plastic dinner-ware and caterers, who provide the boxes of food to be handed out at funerals. Others are the hire companies that rent marquees for shelter and refrigerated trucks in which to keep the food; the wholesalers that supply food and drinks for prestations; the undertakers, the coffin makers, the clergy (who preside, and receive the largest funerary gifts) and the masons who build the tombs and mausoleums.

Lying in their graves, the dead safeguard rights to property in times of changing land tenure norms and uncertainty about traditional inheritance rules. Lying under conspicuous tombs and mausoleums, some of the dead make assertions about the status, wealth, rank or historical importance of the living. And finally, even if their burial places have been long forgotten, the dead are present within the living as providers of personal and family identity, recalled in ancestral narratives, genealogies, myths, legends, history; their work captured in Albert Wendt's poem Inside us the Dead (1976) of which the opening lines are:

\author{
Inside us the dead, \\ like sweet-honeyed tamarind pods \\ That will burst in tomorrow's sun, \\ or plankton fossils in coral alive at full moon \\ dragging virile tides over coy reefs \\ into yesterday's lagoons.
}

\title{
REFERENCES
}

Davidson, Janet, 1969. Settlement patterns in Samoa before 1840. Journal of the Polynesian Society 78 (1): 44-82.

Duranti, Alesandro, 1992. Language and bodies in social space: Samoan ceremonial greetings. American Anthropologist 94 (3): 657-91.

Freeman J. Derek, 1944. The Vailele earthmounds. Journal of the Polynesian Society 53 (4): $145-62$.

Gilson, Richard P. 1970. Samoa 1830-1900: The Politics of a Multi-cultural Community. Melbourne, Oxford University Press.

Grattan, F. J. H., 1948. An Introduction to Samoan Custom. Papakura (NZ): R. MacMillan Publisher.

Herdich, David. J., 1991. Towards an understanding of Samoan star mounds. Journal of the Polynesian Society 100 (4): 381-435. 
Hiroa, Te Rangi [Peter Buck], 1971. Samoan Material Culture. Bernice P. Bishop Museum Bulletin 75. Honolulu. [New York; Kraus Reprint].

Krämer, Augustin, 1995. The Samoa Islands. Volume II. Auckland: Polynesian Press. [Original work published 1902]. Translation by T. Verhaaren.

Laqueur T. W., 2015. The Work of the Dead: A Cultural History of Mortal Remains. Princeton (NJ): Princeton University Press.

Lockwood, Brian, 1971. Samoan Village Economy. Melbourne: Oxford University Press.

Macpherson, Cluny and La'avasa Macpherson, 1990. Samoan Medical Beliefs and Practices. Honolulu, University of Hawai'i Press.

Martinsson-Wallin, Helene, Geoffrey Clark and Paul Wallin, 2006. Monuments and people: A report of the state of the Pulemelei site, Savai'i, Samoa. Journal of Samoan Studies 2: 57-63.

Martinsson-Wallin, Helene, Paul Wallin and Geoffrey Clark, 2007. The excavation of Pulemelei site 2002-2004. Archaeology in Oceania 43: 41-59.

Mead, Margaret, 1969. Social Organization of Manu'a. Bernice P. Bishop Museum Bulletin 76. Honolulu.

Meleisea, Malama and Penelope Schoeffel, 2015. Land, custom and history in Sāmoa. Journal of Samoan Studies 5: 19-29.

Moyle, Richard M. (ed.), 1984. The Samoan Journals of John Williams 1830 and 1832. Canberra: Australian National University Press.

O’Meara, J. Tim, 1987. Samoa: Customary individualism. In R. Crocombe (ed.), Land Tenure in the Pacific. Suva: Institute of Pacific Studies, pp. 74-113.

1990. Samoan Planters: Tradition and Economic Development in Polynesia. New York: Holt, Rinehart and Winston. 1995. From corporate to individual land tenure in Western Samoa. In R.G. Ward and E. Kingdon (eds), Land Custom and Practice in the South Pacific. Cambridge (UK): Cambridge University Press, pp. 109-156.

Schultz, E., 1911. The most important principles of Samoan family law, and the laws of inheritance. Journal of the Polynesian Society 2 (2): 43-53

Thomson, Andrew, 1927. Earth mounds in Samoa. Journal of the Polynesian Society 36 (1): 118-21.

Tuimaleali'ifano, A. Morgan, 2006. O Tama a 'Äiga: The Politics of Succession to Samoa's Paramount Titles. Suva: Institute of Pacific Studies, University of the South Pacific.

Turner, George, 1984. Samoa: A Hundred Years Ago and Long Before. Suva: Institute of Pacific Studies, University of the South Pacific. [Original work published 1884.]

Van der Ryn, F. Micah G., 2012 'The Difference Walls Make': Cultural Dynamics and Implications of Change in Samoan Architectural Traditions and SocioSpatial Practices (1940-2006). Unpublished PhD thesis in Anthropology, The University of Auckland.

Wendt, Albert, 1976. Inside Us the Dead: Poems 1961-1974. Auckland: Pacific Paperbacks. 


\begin{abstract}
In Samoa the selection of burial sites and the type of monuments chosen to mark them not only signify affection and memorialisation, but also make visible statements about traditional rank, and nowadays about family status and claims to property. We examine what is known about burial practices and locations in pre-colonial Samoa and trace the changes that have occurred as a result of 19th-century power struggles, political change, colonial influences and regulations, and new settlement patterns and house-building practices.
\end{abstract}

Keywords: Samoa, graves, burials, mausoleums, tombs, re-interment

\title{
CITATION AND AUTHOR CONTACT DETAILS
}

Meleisea, Malama and Penelope Schoeffel, ${ }^{1}$ 2016. The Work of the Dead in Samoa: Rank, Status and Property. Journal of the Polynesian Society 125 (2): 149-170; DOI: $\mathrm{http} / / \mathrm{dx}$.doi.org/10.15286/jps.125.2.149-170.

${ }^{1}$ Corresponding author: Centre for Samoan Studies, National University of Samoa, PO Box 1622 Lepapaigalagala Campus, To‘omatagi, Samoa. Email: p.schoeffel@ nus.edu.ws 